\title{
Influence of Personality Traits on the Stress Management among the Teaching Faculties in Public Sector Universities
}

\author{
Dr. SADIA ANWAR \\ Assistant Professor, University of Sindh, Pakistan. \\ Email: sadia.memon@usindh.edu.pk \\ Dr. BAHADUR SOOMROO \\ Lecturer, Federal Urdu University of Arts, Sciences and Technology, \\ Abdul Haq Campus, Karachi, Pakistan. \\ Email: bahadur.ali@scholars.usindh.edu.pk \\ Dr. MUHAMMAD NAWAZ BALOCH \\ Associate Professor, University of Sindh Laar Campus@ Badin, Pakistan. \\ Email: mnawaz@usindh.edu.pk
}

\begin{abstract}
This research paper is aimed to explore the influence of personality traits on stress management. As for the achievement of organizational goals, the management has to be assured that its' employees are not stressed due to any reason for productive outcomes. Stress is unavoidable in any organization especially if it belongs to the teaching sector. However, students and teachers are normally found under stress because of the demanding environment that is generated in physical schools and classrooms. For this purpose, this study has examined to what extent personality traits including extraversion, agreeableness, conscientiousness, neuroticism, and openness to experience influence stress management. This leads to the fact which personality traits of employers especially those that belong to educational institutes can manage their stress and how their personality affects them to take decisions at the time of stress. This research article proposed a descriptive methodology in which cross-sectional data are randomly collected from the different public higher educational universities of Sindh, Pakistan. For the data collection, the survey questionnaire is applied. After the process of data cleaning, 252 responses of teaching faculty as respondents were found accurate for further analysis. By applying the Statistical Package for Social Sciences version 26.0 the data was data analyzed. The results of Pearson's correlation and multiple regression analysis showed that agreeableness, conscientiousness, and openness to experience have a positive and significant influence on stress management. On the other hand, extroversion and neuroticism have not found a significant influence on stress management. This research study may provide useful insights for policymakers and top management in public higher educational institutions like universities to identify the stress management strategies that are implemented by the management of education institutions to manage workplace stress among the teaching faculty.
\end{abstract}

Keywords: Extraversion, Agreeableness, Conscientiousness, Neuroticism, Openness to Experience and Stress Management.

\section{Introduction}

It is considered a normal trend for years to have changed like work and the workplace. Because of such changes, the competition that occurs which promotes self-interest may sometimes decline the level of welfare and belief. The intense competition introduced because of globalization has increased the number of acquisitions, mergers, and downsizing initiatives that also explore the insecure employment 
opportunities. Along with employers, the organizations considered as artificial human resources are also under stress to leave behind their competitors and can achieve competitive advantages. Due to which stress in the organizations is a growing phenomenon across the globe. Individuals get emotionally affected due to the behavior of employees causes stress among them that psychologically generates numerous health issues among them. Though the management needs to identify the factors that raise the issues of stress. So that this can be identified that either the stress causes beneficial or destructive for the organization. For this purpose different well-being programs can be arranged to help individuals with stress management at their workplace. However, stress management is considered an influential issue for both organizations and their employees. Managing stress is realizing that the individual is exposed to stressors. As it is difficult to manage stress without identifying the reasons and its consequence that can be physiologically, psychologically, and behaviorally. Therefore, effective stress management can assist the organization to enhance the performance of its employers and of course the organization itself as an artificial human resource. Stress can seem to be either positive or negative. If the circumstances that create stress explore the scenarios to achieve the advantages this will be considered as positive stress. However, if such circumstances create health hazards, intoxication, absenteeism, and other organizational problems, it will be considered as negative (Reddy \& Jagannayaki, 2018; Annapurna, 2020). Stress can be the cause of various conditions as psychological, heart diseases and can also bring instabilities in individuals' social, company, emotional, and family life also.

It is essential to identify the sources of job stress so that the employee's mental and physiological health can be managed for the achievement of excellent performances by them. Stress at the workplace can be defined as situations where job-related factors interact with the employers to change their psychological and physiological conditions so that the individual can deviate from normal functioning (Newman \& Beehr,1979; Reddy \& Jagannayaki, 2018; Annapurna, 2020). Reasons of stress at workplace may include incompetence to meet the job demands, friendly relationship with subordinates, leadership, acting as a trainer, seniors, colleagues and juniors' support, role conflicts, excessive work pressure, excessive workload, to meet deadlines, to be creative, interpersonal conflicts, the lack of progress, to produce new publications in a research area, not being promoted, working overtime and on holidays, change of job, work against will, harassment, etc. (Shinn et al., 1984; Geo Poul, 2010; Patro \& Kumar, 2019). Such stressors can create hindrances in the performance of employers in the organization. The primary stage to have stress management among the employers has still some significant limitations, as no efforts are made to alter the sources of work stress. Because such efforts can affect the organizational change by higher management with the psychological fallacy assuming that organizations are formed by human resource, thus the organization can be changed by changing its human resource so it remains stuck to individual centered methods (Murphy \& Sorenson, 1988; Jeyaraj, 2013; Dua, \& Sangwan, 2016). Thus, in such conditions stress at the workplace occurs due to an imbalance between the perceived pressures and demands of the work environment along with the capability of employees to manage it. The employees can manage their stress by the level of control they have over their working condition, along with the support which they receive from their subordinates and through the approaches which they use to manage the work pressures. Like other organizations, the employees of educational institutions also face serious issues considered as stressors in the shape of job insecurity, long hours, continuous change, and unrealistic deadlines, which sometimes become problematic for them also (Vijayadurai \& Venkatesh, 2012; Annapurna, 2020).

Thus, in such a situation personality of individuals plays a significant role in managing all such working pressure issues (Annapurna, 2020). The literature on personality suggests that five personality dimensions have been employed by academic researchers to investigate its role among the academicians (Reddy \& Jagannayaki, 2018). These five traits of personality are extraversion, agreeableness, neuroticism, conscientiousness, and openness to experience. Extraversion people are very outgoing, social, and positively communicate with others in their life. Agreeableness talks about the kind, cooperative, selfless, and generous nature of personality. Neuroticism is opposite to emotional stability. Emotionally stabled people remain self-confident, cool, and calm in their dealings. Conscientiousness is defined as the extent to which an individual is diligent, efficient, organized, and hard-working. Openness to experience is 
concerned with how much an individual is ready to face new challenges and innovative tasks (Barrick \& Mount, 1991; Salgado, J.F, 1997; Walt, Meiring, Rothmann, \& Barrick, 2002; Özbağ, 2016; Feher \& Vernon, 2020). Thus, higher educational institutions are the place from where the personalities are developed individuals to face the challenges of the world, if the employees are the teaching faculty feel occupational stress, how they can be able to teach the students to manage their personalities to cope up with any situation (Bhatia \& Goyal, 2018). Thus, the authorities of higher education should provide appropriate attention to the financial problems and working environment so that the personalities of employees should not be negatively affected (Suganya \& Rajkmar 2016). Due to the above-mentioned issues, it has been explored that the personalities of teaching faculty play a significant role in the academics. Therefore, the objective of this research is to highlight the influential effect of personality traits to manage the stress among the teaching faculty of public sector universities.

This research explore a research gap in this domain That, there is still a need for further research highlighting the influence of individuel personality traits on stress management. Additionally, the academic literature on individual behaviors and strategies required for stress management needs more attention from the eastern perspective (Bukhsh, Shahzad, \& Nisa, 2011; Kumari \& Saradadevi, 2016; Sri, 2019) whereas this research will be carried out in a developing country. This study will contribute to the literature of organizational behavior by adopting an interactive approach of empirically examine the influence of personality trait factors such as extroversion, agreeableness, neuroticism, conscientiousness, and openness to experience on stress management. Also, the scope of this research will contribute to the domain of human resource management as general and particularly focusing the developing countries like Pakistan.

\section{Literature Review}

The current literature shows that teaching is considered a high-stress and more challenging profession than other professions (Aditi \& Kumari, 2005; Devi, 2007; Poul, 2010). Some opinion about this profession is based on negative emotions described as anger, anxiety, frustration or depression, fatigue and difficulty concentrating (Mehta \& Kumar, 2009; Jeyaraj, 2013; Dua, \& Sangwan, 2016). Based on such descriptions, different researchers analyzed different relationships among the stress and strategies used by the employees to manage it, stress and burnout syndrome (Vijayadurai \& Venkatesh, 2012; Reddy \& Jagannayaki, 2018; Zhou, Da, Guo, \& Zhang, 2018; Patro \& Kumar, 2019). Several studies have investigated the differences in individual characteristics which lead them to understand how individuals react towards the positive or negative outcomes of stress. The variables of locus of control and personalities, which are majorly characterized by the Big Five traits and self-efficacy theory explore that the properties of an individual are either their vulnerabilities to disease or they can be considered the methods of flexibility to manage according to the stressed situations (Carlson \& Thompson 1995; Jeyaraj, 2013; Dua \& Sangwan, 2016). One of the research that was conducted on teachers identified that the most significant sources of stress include the inadequate salary, extensive workload, lack of control, teacher-student ratio, lack of social support from supervisors and co-workers, student misbehavior, and mobbing (Pyżalski, 2010). Thus, the personality traits of teachers can only be established to increase vulnerability to stress-related psychological behaviors (Rademaker, Kleber, Geuze \& Vermetten 2009). Regarding teacher personality, the Eysenck model of personality explores the relationship between high scores in neuroticism, introversion, and psychological illness and burnout that is followed by other studies in which stress levels and stress-related disorders such as burnout are discussed by observing the behavior of teachers (Fontana \& Abouserie, 1993; Langelaan, Bakker, Doornen \& Schaufeli, 2006). The characteristics of individuals are mostly found as a high level of neuroticism, negative affectivity in the case of burnout syndrome (Thoresen, Kaplan, Barsky, Warren \& Chermont, 2003). However, the unpredictable traits responsible for low abilities of motivation processing such as high determination and emotional reactivity, low tendency to sensation seeking (Langelaan, Bakker, Doornen \& Schaufeli, 2006; Palczynska \& Mojsa, 2006). Therefore, these traits constitute the profile of burnout syndrome among the employees of organizations. Whereas, a protective personality profile of well-managed individuals in terms of flexibility, internal integration, and good emotional control makes it easy for them to deal with any such burnout syndromes (Tucholska, 2003). 
Hence, stress management programs can help in managing the well-being of employees by reducing their psychological stress due to work productivity, by overcoming their fear of failing to manage their work stress and facing health problems, which ultimately improve job satisfaction among the employers of organizations (Patro \& Kumar, 2019). Thus, different role stressors are also experienced by the teachers' professionals (Poul, 2010). It is explored that many teaching faculty are victims of a high level of occupational stress because of lack of interaction, work pressures, social status, excessive workload, poor working conditions (Jeyaraj, 2013). One of the major issues that were faced by the female faculty includes the poor working conditions, scarcity of resources, heavy workloads, and lack of administrative and family support system (Dua \& Sangwan, 2016). Along with this, it was also identified working females also face more family conflicts and cannot balance in family and job because of not getting proper support from their in-laws with whom they live (Bukhsh, Shahzad, \& Nisa, 2011; Kumari \& Saradadevi, 2016; Sri, 2019). One of the factors that are considered as a major cause of stress among employees is less experience and inadequate facilities (Suganya \& Rajkmar, 2016).

Various researches explore that five traits of personality are considered as highly predictors of different workplace behavior. Among the five traits, agreeableness was considered to be the best interpreter of counterproductive workplace behavior. Individuals having low agreeableness are revengeful, selfish, full of conflict, and lack of consistency. Individuals having the neuroticism trait is having a positive impact on counterproductive workplace behavior. People with low emotional stability are anxious, stress-prone, and unhappy to interact with others. Whereas, emotional stability directly linked with counterproductive workplace behaviors (Ones, Viswesvaran, \& Schmidt, 1993; Donovan, 2000; Barrick, Mount, \& Judge, 2001; Douglas \& Martinko, 2001; Hurtz \& Jensen-Campbell \& Graziano, 2001; Salgado,J.F; Cullen \& Sackett, 2003; Mount, Ilies, \& Johnson, 2006; Sackett, Berry, Wiemann, \& Laczo, 2006; Berry, Ones, \& Sackett, 2007; Iqbal \& Hassan, 2016). However, conscientiousness and agreeableness are found positive predictors of job performance. Conscientious people are highly responsible, devoted, organized, and hard workers, thus this factor is also considered as a strong predictor of job satisfaction. Openness to experience and extraversion has been seen with no impact or with negative influence over job performance in some researches. (Barrick \& Mount, 1991; Barrick et al., 2001; Barrick, Stewart, Neubert, \& Mount, 1998; Hogan, 1996; John \& Srivastava, 1999; Liao \& Chuang, 2004; Witt, Burke, Barrick, \& Mount, 2002). For that reason, the current study efforts to identify the influence of personality traits towards stress management in public sector educational institutions to manage workplace stress among teaching faculty.

\section{Relationship Between Personality Traits and Stress Management}

Individuals face different kinds of stress which they receive either from the society in which they live or from their workplaces. No doubt that life is full of stressful events, but when individuals start their careers the key stressors are related to the workplace, its environment, and its employers. Stress is the reaction of the body due to interaction with any stimulus in the environment. Thus, based on current literature it explored that the profession of teaching is recognized as a stressful job globally (Skaalvik \& Skaalvik, 2016). One of the factors that have been identified as the cause of stress among the teachers is the relationship between students and teachers (Malek \& Ajmal, 2010; Danyluk, 2013). Stress can be defined as a cause of any act that is internally or externally are harder to adapt by the individuals, and it requires great efforts for the individuals to maintain the equilibrium among themselves and of the external environment (Abebe \& HaileMariam, 2011). The two main kinds of stressor include personal stressors that deals with the perceptions and internal feeling of individuals that sometimes become hard to manage. However, another is the situational stressors that react to the specific incidence like a student fight is witnessed by teachers. Stressors are all over, though the individuals react to stress differently or it depends on how one person can handle better with internal stress than another person because responses to stress cannot be taken as universal (Xin et al., 2017). The previous perception about the stress is based on different and instability of mindset to deal with the demand in a situation and the related strategies (Okeke, Adu, Drake \& Duku, 2014; Okeke, Shumba, Rembe, \& Sotuku, 2015). Hence, the teachers should also require to manage their emotions because it will become beneficial for teachers to enhance their capabilities 
to deal with the students (Alhebaishi, 2019). Therefore, to deal with the stressful situation, teachers need to manage their personalities to handle the situation and also teach students to maintain their personalities as the teachers are role models for students.

Research has revealed that there is an intellectual reasoning behind the personality traits that are comprised of factors like environmental personal and behavioral factors which maintain the actions of all the individuals (Qureshi, 2015). Personal factors are characterized as knowledge, expectation, and attitude, however standards of society, that affect the attitudes of people are considered as environmental factors (Mahler et al., 2018). The term personality is demarcated as the set of psychological traits and approaches within the individual, with which they systematized and relatively influence their interactions to deal with the intra-psychic, physical and social environments (Larsen \& Buss, 2014). Thus, one of the research associates the big five personality traits categorized of extraversion, agreeableness, conscientiousness, openness to experiences, and emotional stability with human values (Cloninger et al., 1993; De Raad \& van Oudenhoven, 2008; Stankov, 2007; Athota \& O'Connor, 2014). The personality traits found in individuals majorly have moral foundations that are moderately inborn, including extraversion, neuroticism, agreeableness, conscientiousness, or openness to experience (Keller, Coventry, Heath, \& Martin, 2005; Goldberg, 2014). Though extraversion is of being in the company of others as talkative and assertive, whereas neuroticism refers to emotional instability and is a state that is prone to negative emotions, anxiousness, and insecurity (Raynor \& Levine, 2009). Agreeableness deals with the activities related to cooperation, and teamwork (Bartram, 2005). Conscientious personalities are mostly found dependable, orderliness, and rule-adherence (Tett et al., 2000). According to Bartram (2005) conscientiousness, individuals are organizing and executing. Openness to experience explores the personals with seeking input, creative thinking, and cultural appreciation (Tett et al., 2000). These conceptual overlaps help us to understand how people build bonds, influence one another, and establish social groups. According to the perception of Cattel personality is considered a cognitive-behavioral model that reacts differently in different situations (Burisch, 2002; Bakker, Killmer, Siegrist, \& Schaufeli, 2000). Thus, in the research era, the Big Five is the most common model in the study of personality. This model is consisting of extroversion, agreeableness, neuroticism, conscientiousness, and openness to experience (Burisch, 2002; Halbesleben, \& Buckley, 2004; Swider \& Zimmerman, 2010) Various studies have tried to explore the main personality traits predictors to manage stress (Karasek, \& Theorell,1990; Lundstrom, Graneheim, Eisemann, Richter, \& Astrom, 2007; Veugelers \& Vedder, 2003). Therefore, in this, the researchers explore the influence of personality traits on stress management. The following hypotheses are as follows:

H1: Extroversion has a significant influence on stress management.

H2: Agreeableness has a significant influence on stress management.

H3: Neuroticism has a significant influence on stress management.

H4: Conscientiousness has a significant influence on stress management.

H5: Openness to experience has a significant influence on stress management.

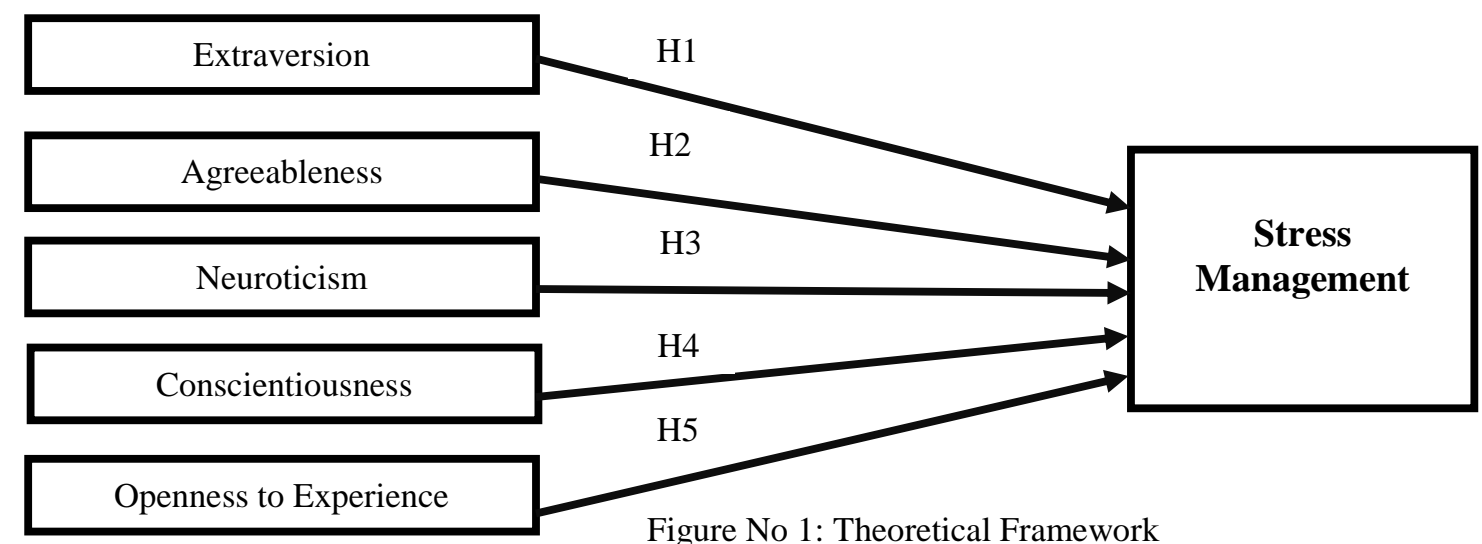




\section{Methodology adopted for research}

In this research study, the descriptive survey is used for the accomplishment of the research design. To attain the objective of the research the teaching faculty of public universities were selected as population. Among the 18 public sector universities of Sindh, the data was collected from the following universities through random sampling so that every faculty can get a chance to participate. Such universities include the University of Sindh, Jamshoro, Mehran University of Engineering and Technology, Jamshoro, Institute of Business Administration, Karachi, Shah Abdul University Khairpur, Sukkur Institute of Business Administration, Sukkur. The experiential analysis of this research is to identify the influence of Big Five personality traits on stress management among the faculty members working in different public sector universities of Sindh. The completion of this research has been done through the primary data collected through a survey instrument that was developed of required items of respective factors from the prior data. The survey questionnaire was based on 5 point Likert scale. The satisfactory overall reliability of the survey instrument was found at 0.845 . Thus, this research study was further continued, after fulfilling all the necessary assumptions and requirements of reliability and construct validity of the questionnaire. This research determined the sample size as employees working called teaching faculty members in public sector higher educational institutions of Sindh. The random sampling technique was adopted for the collection of sample data properly. Initially, 500 survey questionnaires were distributed among the respondents via Google form, emails, and also by visiting personally. Through which 500, 259 respondents returned with a response rate of $51 \%$ approximately. Among all the received feedback in total, 252 valid questionnaires were found applicable after data cleaning and screening for analysis.

\section{Data analysis and results}

Received data was analyzed through the process of Statistical Package for Social Sciences (SPSS) 26.0 version. Further analysis was accomplished through various statistical tests required for the research.

\section{Respondents' demography}

The demographic of respondents indicates the male participants $42.48 \%(n=107)$ that are less than the female respondents which were $57.522 \%(\mathrm{n}=145)$. The majority of respondents were having age 31-35 having $49.6 \%(n=124)$ whereas only $13.82 \%(n=15)$ were of 36 years and above age. Though, $65.09 \%(n=164)$ respondents were married and $21.5 \%(n=54)$ were unmarried. (Table.1).

Table 1: Respondents' Demography ( $\mathrm{N}=252)$

\begin{tabular}{|cccc|}
\hline \multirow{6}{*}{ Gender } & Category & Frequency & Percent \\
\cline { 2 - 4 } & Male & 107 & 42.48 \\
& Female & 145 & 57.52 \\
& Total & 252 & 100.0 \\
\cline { 2 - 4 } & $21-25$ & 48 & 19.08 \\
& $26-30$ & 44 & 17.5 \\
& $31-35$ & 124 & 49.6 \\
& 36 and above & 15 & 13.82 \\
& Total & 252 & 100.0 \\
\hline \multirow{6}{*}{ Status } & Married & 164 & 65.09 \\
& Divorced & 22 & 8.73 \\
& Unmarried & 54 & 21.5 \\
& Widow & 12 & 4.68 \\
& Total & 252 & 100.0 \\
\hline
\end{tabular}




\section{Descriptive statistics and reliability assessment}

Mean was having a maximum range of 3.95, however the minimum range was 2.75 (Table 2). Furthermore, a maximum range for standard deviation was analyzed as 1.74., however the minimum range of standard deviation was perceived as 0.41 (Table 2). Though, the reliability of each factor was found above 0.5 which is considered satisfactory, although overall reliability was observed as 0.831 (Table. 2).

Table 2: Descriptive statistics and Cronbach's alpha (N=252)

\begin{tabular}{|llccc|}
\hline No. & Variables & M & SD & $\alpha$ \\
\hline 1 & Stress Management & 3.78 & 1.55 & 0.89 \\
2 & Extroversion & 3.39 & 0.42 & 0.85 \\
3 & Agreeableness & 3.48 & 0.89 & 0.81 \\
4 & Neuroticism & 2.75 & 1.74 & 0.79 \\
5 & Conscientiousness & 3.78 & 0.41 & 0.78 \\
6. & Openness to experience & 3.95 & 0.54 & 0.88 \\
\hline
\end{tabular}

Note: $\mathrm{M}=$ mean; $\mathrm{SD}=$ standard deviation; $\alpha=$ Cronbach's alpha reliability

\section{Hypotheses Analysis}

With the assistance of Multiple Regression Analysis and Pearson's correlation the analysis was accomplished. Data analysis explored that neither the correlation between extroversion and stress management nor the independent influence of extroversion on stress management $(\mathrm{r}=0.224 ; \beta=-0.192 ; \mathrm{t}=$ $6.210 ; \mathrm{p}<0.01$ ) (see Table $3 \& 4$ ). Therefore, H1 is not accepted. The significant positive correlation between agreeableness and stress management $\left(\mathrm{r}=0.471^{* * *}\right)$ (see Table 3$)$; agreeableness has $\left(\mathrm{r}=0.471^{\text {*** }} ; \beta\right.$ $=0.433 ; \mathrm{t}=5.61^{*} ; \mathrm{p}<0.000$ ) (see Table 3 and 4 ) that supported the hypothesis H2. Similarly, the weightage score of influence of neuroticism towards stress management were $(r=0.199 ; \beta=-0.103 ; \mathrm{t}=$ $0.321 ; \mathrm{p}<0.01$ ) (see Table 3 and4) that also showed neither the individual correlation nor the independent influence of neuroticism on stress management. Thus, the $\mathrm{H} 3$ was not accepted. The analysis for hypothesis H4 weights $\left(\mathrm{r}=0.148^{* *} ; \beta=0.355 ; \mathrm{t}=8.322 ; \mathrm{p}<0.000\right)$ (Table 3 and 4$)$ that confirmed a significant correlation and influence of conscientiousness on stress management. As a result, H4 was also accepted through the analysis. Finally, there was a significant positive correlation between openness to experience and stress management $\left(\mathrm{r}=0.209^{* *}\right)$ (see Table 3); openness to experience made a significant independent influence on stress management $(r=0.209 * * ; \beta=0.268 ; \mathrm{t}=4.503 ; \mathrm{p}<0.000)$ (see Table $3 \& 4)$. Therefore, H5 is also accepted.

Table 3: Pearson's Correlation $(\mathrm{N}=252)$

\begin{tabular}{|c|l|c|c|c|c|c|}
\hline S.No & \multicolumn{1}{|c|}{ Variables } & 1 & \multicolumn{1}{c|}{2} & 3 & 4 & 5 \\
\hline 1 & Stress Management & --- & & & & \\
\hline 2 & Extroversion & 0.224 & --- & & & \\
\hline 3 & Agreeableness & $0.471^{* *}$ & $0.432^{* *}$ & --- & & \\
\hline 4 & Neuroticism & 0.199 & 0.496 & 0.291 & --- & \\
\hline 5 & Conscientiousness & $0.148^{* *}$ & $.405^{* *}$ & .326 & $.177^{*}$ & --- \\
\hline 6 & Openness to experience & $.209 * *$ & $.368^{* *}$ & $.107^{*}$ & $-124^{*}$ & $-.340^{* *}$ \\
\hline
\end{tabular}

**. Correlation is significant at the 0.01 level (2-tailed).

*. Correlation is significant at the 0.05 level (2-tailed). 
Table 4: Multiple Regression Analysis ( $\mathrm{N}=252)$

\begin{tabular}{|llll|}
\hline Independent variables & $\boldsymbol{\beta}$ & t- value & Sig. \\
\hline Extroversion & -0.192 & 6.210 & 0.01 \\
Agreeableness & .433 & $5.61^{* *}$ & 0.000 \\
Neuroticism & -0.103 & 0.321 & 0.01 \\
Conscientiousness & 0.355 & 8.322 & 0.000 \\
Openness to experience & 0.268 & 4.503 & 0.000 \\
\hline F value & 123.719 & & \\
$\mathrm{R}^{2}$ & 0.559 & & \\
Adjusted $\mathrm{R}^{2}$ & 0.549 & & \\
\hline
\end{tabular}

Dependent variable: Stress Management Note: $\mathrm{p}^{*}<0.01 ; \mathrm{p}^{* *}<0.05$

\section{Discussion}

This research study identified the factors of personality traits towards stress management in the province of Sindh, Pakistan. This research has adopted cross-sectional strategies for data collection. This research developed a conceptual model based on the literature review. The influence of personality traits was analyzed on stress management as a dependent variable while extroversion, agreeableness, neuroticism, conscientiousness, and openness to experience were scrutinized as independent variables. The collection of data was accomplished from teaching faculty of public sector universities through a survey questionnaire established from the related literature. Before the analysis process, the reliability and validity of the questionnaire were confirmed through the Statistical Package for Social Sciences (SPSS) version 26.0 for windows. The internal consistency (reliability) among the items was found satisfactory. Thus, the analysis explored that the $\mathrm{H} 1$ and $\mathrm{H} 3$ were not accepted in this research study, as in research it has been found that individual having the personality with extroversion and neuroticism characteristics are having influences of power and achievement that make them self-centered which also affect the moral foundations of their values (Athota, Budhwar, \& Malik, 2020). Thus, this research supports the assumption of this research that extroversion and neuroticism has not a significant impact on stress management. However, the $\mathrm{H} 2, \mathrm{H} 4$, and $\mathrm{H} 5$ explored the positive influence of agreeableness, conscientiousness, and openness to experience on stress management among the employees of educational institutes. Several research studies confirmed such influence as (Karasek \& Theorell,1990; Lundstrom, Graneheim, Eisemann, Richter, \& Astrom, 2007; Veugelers \& Vedder, 2003; Mojsa-Kaja, Golonka, \& Marek, 2015) in the different contexts. However, extroversion and neuroticism were not found any positive influence on stress management that is also confirmed from different research studies (Bartram, 2005; Raynor \& Levine, 2009)

\section{Conclusion, Recommandations, and Limitations}

Thus, the factor of stress is mostly gained because of work pressure and work-life imbalance. In this regard, the organization should manage and raise their roles to assist their employees to balance among the family and work. The human resource can only be effective as much as the organization found themselves as concerned. The stress management programs are required for evaluation, counseling programs, program interventions, and inter-personal initiatives lead to higher motivation levels among the faculty members to achieve the objectives of the organizations.

Stress management is a real challenge for all the employees working in the organizations. If organizations work to transform their work environment that can reduce the stressors which employees normally faced in the working places. Along with this, it is also important that organizations monitored the stress problems with the management of educational institutions. Though identifying the problem of stress is not enough, the organizations should also promote healthy work and reduced harmful aspects of work in the organizations. 
This research explores the influential effects of personality traits on stress management in public sector universities in Sindh. A positive and negative influence was identified among these variables. The present research analysis was mostly supported by the previous studies in the literature. However, some of the limitations like all other researches are found in the research design of this study. As different work stressors are not identified through the different personality traits. From person to person, the personality reacts differently along with the circumstances though such factors can be entered as mediators because this can have a reciprocal impact on stress management in the different public and private sectors. Hence, different study is recommended using different factors of personality traits and stress management so that higher management can fully recognize and appreciate the appropriate methodology that will effectively enhance performance in specific public sector organizations. Consequently, it is recommended that similar studies could be carried out in the private sector to explore the influence of personality traits on stress management. This will assist to explore the differences between the public and private educational sectors. Also, this research has been conducted within a small geographic area of Sindh, which can affect the validity of generalization. More researches should be conducted in a wider scope that should be on a national level. Some of the recommendations for the educational institutions that they should look forward to the financial problems, work pressures, and working environment. The higher authorities must have inadequate communication with the stressed individuals to reduce such stress. Or should manage a positive attitude with the employees so that they can face the problems relax and with motivated attitudes.

Some practical implication of this research study to the authorities of higher educational institutions is that they should be informed of any type of organizational changes that can enhance the stress among the faculty members, such stress can be reduced through proper communication, guidance, and positive attitude with the colleagues so that they can perform their responsibilities efficiently and effectively. The faculty members should be providing proper training sessions of yoga, meditation, muscle relaxation and mindfulness breathing, stress management techniques that can develop their personalities mentally and physically strong to manage any stressful situation.

\section{References}

Aditi, N., \& Kumari, B. (2005). Impact of personality patterns and employment status on psychological stress tolerance of women in Kerala. Indian Psychological Review, 64(2), 103-108.

Abebe, S., \& Haile Mariam, A. (2011). Teacher stressors and potential remedies from pre-service teachers' and cooperating teachers. Eastern Education Journal, 40(1), 64-74.

Alemu, Y., Teshome, A., Kebede, M., \& Regassa, T. (2014). Experience of stress among student- teachers enrolled in postgraduate diploma in teaching (PGDT): The case of Haramaya University cluster centers, Ethiopia. African Educational Research Journal, 2(3), 96-101.

Alhebaishi, S. M. (2019). Investigation of EFL student teachers' emotional responses to affective situations during practicum. European Journal of Educational Research, 8(4), 1201-1215, http://doi.org/10.12973/eu-jer.8.4.1201.

Anitha Devi, S. (2007). Occupational stress: A comparative study of women in different occupations. Prajnan, 35(1), 61-74.

Annapurna, A. (2020). Stress Management among Women Employees in Education Institutions - A Study. International Journal for Research in Applied Science and Engineering Technology, 8(1), 572-579. https://doi.org/10.22214/ijraset.2020.1105.

Athota, V.S., \& O'Connor, P.J. (2014). How approach and avoidance constructs of personality and emotional management predict core human values. Learning and Individual Differences, 31, 51-58.

Bakker, A.B., Killmer, Ch.H., Siegrist, J., Schaufeli, W.B.(2000). Effort-reward imbalance and burnout among nurses. J Adv Nurs. 31(4): 884-91, http://dx.doi.org/10.1046/j.1365- 2648.2000.01361.x.

Barrick, M. R., \& Mount, M. K. (1991). The big five personality dimensions and job performance: a meta-analysis. Personnel psychology, 44(1), 1-26. 
Barrick, M. R., Mount, M. K., \& Judge, T. A. (2001). Personality and performance at the beginning of the new millennium: What do we know and where do we go next? International Journal of Selection and Assessment, 9(1-2), 9-30.

Barrick, M. R., Stewart, G. L., Neubert, M. J., \& Mount, M. K. (1998). Relating member ability and personality to work-team processes and team effectiveness. Journal of Applied psychology, 83(3), 377.

Berry, C. M., Ones, D. S., \& Sackett, P. R. (2007). Interpersonal deviance, organizational deviance, and their common correlates: a review and meta-analysis. Journal of Applied psychology, 92(2), 410.

Bhatia, K., \& Goyal, A. (2018). An analytical study of occupational stress and its impact on employee performance with reference to the female. International Journal of Research and Analytical Reviews, 5, 296-308.

Bukhsh, Q., Shahzad, A., \& Nisa, M. (2011). A study of learning stress and stress management strategies of the students of postgraduate level: A case study of Islamia university of Bahawalpur, Pakistan. Procedia - Social and Behavioral Sciences, 30(May 2014), 182-186. https://doi.org/10.1016/j.sbspro.2011.10.036.

Burisch, M. (2002). A longitudinal study of burnout: The relative importance of dispositions and experiences. Work Stress, 16(1):1-17, http://dx.doi.org/10.1080/02678370110112506.

Cano-Garcia, F.J., Padilla-Munoz, E.M., Carrasco-Ortiz, M.A. (2005). Personality and contextual variables in teacher burnout. Pers Individ Dif, 38(4), 929-40, http://dx.doi.org/10.1016/j.paid.2004.06.018.

Carlson, B.C., Thompson, J.A., (1995). Job burnout and job leaving in public school teachers: Implications for stress management. Int J Stress Manage, 2(1), 15-29, http://dx.doi.org/10.1007/BF01701948.

Cloninger, C.R., Svrakic, D.M., \& Przybeck, T.R. (1993). A psychobiological model of temperament and character. Archives of General Psychiatry, 50, 975-990.

Cullen, M. J., \& Sackett, P. R. (2003). Personality and counterproductive workplace behavior. Personality and work: Reconsidering the role of personality in organizations, 14(2), 150-182.

Danyluk, P. (2013). The role of the pre-practicum in lessening student teacher stress: Student teachers' perceptions of stress during practicum. Action in Teacher Education, 35(5-6), 323-334.

De Raad, B., \& van Oudenhoven, J.P. (2008). Factors of values in the Dutch language and their relationship to factors of personality. European Journal of Personality, 22, 81-108.

Dollinger, S.J., Leong, F.T.L., \& Ulicni, S.K. (1996). On traits and values: With special reference to openness to experience. Journal of Research in Personality, 30, 23-41.

Douglas, S. C., \& Martinko, M. J. (2001). Exploring the role of individual differences in the prediction of workplace aggression. Journal of Applied psychology, 86(4), 547.

Dua, K., \& Sangwan, V. (2016). Study on Stress and Stress Management Mechanisms. International Journal of New Innovations in Engineering and Technology, 5(3), 51-53.

Fontana, D.R., \& Abouserie, R. (1993). Stress levels, gender and personality factors in teachers. Brit J Educ Psychol,63(2), 261-70, http://dx.doi.org/10.1111/j.2044-8279.1993.tb01056.x.

Feher, A., \& Vernon, P. A. (2020). Looking beyond the Big Five: A selective review of alternatives to the Big Five model of personality. Personality and Individual Differences, (March), 110002. https://doi.org/10.1016/j.paid.2020.110002

Geo Poul, K. (2010). Occupational Stress among High School Teachers. Journal of Organisational Management, 26(2), 44-48.

Goldberg, L.R. (2014). NEO Domains Table (October 19, 2014). Retrieved from http://ipip.ori.org/newNEO_Domains

Halbesleben, J.R.B., \& Buckley, R.M. (2004). Burnout in organizational life. J Manage, 30(6),859-79, http://dx.doi.org/10.1016/j.jm.2004.06.004.

Hurtz, G. M., \& Donovan, J. J. (2000). Personality and job performance: The Big Five revisited. Journal of Applied psychology, 85(6), 869.

Iqbal, Q., \& Hassan, S. H. (2016). Role of Workplace Spirituality: Personality Traits and Counterproductive Workplace Behaviors in Banking Sector. Online International Journal of Management, Accounting and Economics, 3(12), 806-821. Retrieved from www.ijmae.com

Jensen-Campbell, L. A., \& Graziano, W. G. (2001). Agreeableness as a moderator of interpersonal conflict. Journal of personality, 69(2), 323-362. 
Jeyaraj, S. S. (2013). Occupational stress among the teachers of the higher secondary schools in Madurai District, Tamil Nadu. IOSR Journal of Business and Management, 7(5), 63-79.

John, O. P., \& Srivastava, S. (1999). The Big Five trait taxonomy: History, measurement, and theoretical perspectives. Handbook of personality: Theory and research, 2, 102-138.

Karasek, R., \& Theorell, T. (1990). Stress, productivity, and the reconstruction of working life. New York: Basic Books, Inc, 1990.

Keller, M.C., Coventry, W.L., Heath, A.C., \& Martin, N.G. (2005). Widespread evidence for no additive genetic variation in Cloninger's and Eysenck's personality dimensions using a twin plus sibling design. Behavior Genetics, 35, 707-721.

Klassen, R. M., \& Durksen, T. L. (2014). Weekly self-efficacy and work stress during the teaching practicum: A mixed methods study. Learning and Instruction, 33, 158-169. https://doi.org/10.1016/j.learninstruc.2014.05.003.

Kumari, G. K., \& Saradadevi. (2016). A study on stress management of working women in twin cities. International Journal of Scientific Development and Research, 1(4), 294-298.

Langelaan, S., Bakker, A.B., Doornen, L.J.P., \& Schaufeli, W.B. (2006). Burnout and work engagement: Do individual differences make a difference? Pers Individ Dif, 40(3),521-32, http://dx.doi.org/10.1016/j.paid.2005.07.009.

Larsen, R.J., \& Buss, D.M. (2014). Personality psychology: Domains of knowledge about human nature, 5th edition. New York: McGraw-Hill.

Liao, H., \& Chuang, A. (2004). A multilevel investigation of factors influencing employee service performance and customer outcomes. Academy of Management Journal, 47(1), 41-58.

Mojsa-Kaja, J., Golonka, K., \& Marek, T. (2015). Job burnout and engagement among teachers - Worklife areas and personality traits as predictors of relationships with work. International Journal of Occupational Medicine and Environmental Health, 28(1), 102-119. https://doi.org/10.13075/ijomeh.1896.00238

Murphy, L.R, \& Sorenson, S. (1988). Employee behaviors before and after stress management, Journal of organizational behavior, 9, 173-182.

Lundstrom, M., Graneheim, U.H., Eisemannm, H., Richter, J., \& Astrom, S. (2007). Personality impact on experiences of strain among staff exposed to violence in care of people with intellectual disabilities. $J$ Policy Pract Intellect Disabil, 4(1), 30-9, http://dx.doi.org/10.1111/j.1741-1130.2006.00095.x.

Maddux, J.E. (2011). Self-efficacy: The power of believing you can. In C. R. Snyder \& S.J. Lopez (Eds), Handbook of positive psychology. New York, NY: Oxford University Press.

Mahler, D., Großschedl, J., \& Harms, U. (2018). Does motivation matter? - The relationship between teachers' self-efficacy and enthusiasm and students' performance. PLoS ONE, 13(11), 1-19. https://doi.org/10.1371/journal.pone.0207252.

Malik, S., \& Ajmal, F. (2010). Levels, causes and coping strategies of stress during teaching practice. Journal of Law and Psychology, 1(1), 2078-1083.

Mehta, S., \& Kumar, S. (2009). Comparative Study of Organisational Role Stress among Technical and non-Technical Teachers. Journal of Organisational Behaviour, 8(1), 70-76.

Moradi, H., \& Ardahaey, F. T. (2011). The role of emotional intelligence in organizational commitment. Retrieved from http://dx.doi.org/10.2139/ssrn.1848523.

Mount, M., Ilies, R., \& Johnson, E. (2006). Relationship of personality traits and counterproductive work behaviors: The mediating effects of job satisfaction. Personnel psychology, 59(3), 591-622.

Nordin, N. (2012). Assessing emotional intelligence, leadership behaviour and organizational commitment in a higher learning institution. Procedia - Social and Behavioral Sciences, 56, 643-651. https://doi.org/10.1016/j.sbspro.2012.09.699.

Okeke, C. I. O., Adu, E. O., Drake, M. L., \& Duku, N.S. (2014). Correlating demographic variables with occupational stress and coping strategies of pre-school educators: A literature review. Journal of Psychology, 5(2), 143-154.

Okeke, C. I. O., Shumba, J., Rembe, S., \& Sotuku, N. (2015). Demographic variables, work-stimulated stressors and coping strategies of pre-school educators: A concept paper. Journal of Psychology, 6(1), 91-101. 
Ones, D. S., Viswesvaran, C., \& Schmidt, F. L. (1993). Comprehensive meta-analysis of integrity test validities: Findings and implications for personnel selection and theories of job performance. Journal of Applied psychology, 78(4), 679.

Özbağ, G. K. (2016). The Role of Personality in Leadership: Five Factor Personality Traits and Ethical Leadership. Procedia - Social and Behavioral Sciences, 235(October), 235-242. https://doi.org/10.1016/j.sbspro.2016.11.019.

Palczynska, E., \& Mojsa, J. (2006). Does the psychoterapists's temperament influence the professional burnout syndrome? Research report. Ergonomia IJE\&HF, 28(4) ,229-36.

Patterson, C.M., Kosson, D.S., \& Newman, J.P. (1987). Reaction to punishment, reflectivity, and passive avoidance learning in extroverts. Journal of Personality and Social Psychology, 52, 565-575.

Patro, C. S., \& Kumar, K. S. (2019) Effect of Workplace Stress Management Strategies on Employees' Efficiency. International Journal of Scientific Development and Research, 4(5), 412-418.

Pyżalski, J., \& Merecz, D. (2010). [Psychosocial working conditions of Polish teachers. Between Burnout and engagement]. Kraków: Oficyna Wydawnicza Impuls, 53-74.

Qureshi, R. (2015). They are able who think they are able: Relationship between self-efficacy and in service teacher education. International Journal on New Trends in Education and Their Implication, 6(2), 93-103.

Rademaker, A.R., Kleber, R.J., Geuze, E., \& Vermetten, E. (2009). Personality dimensions' harm avoidance and self-directedness predicts the cortisol awakening response in military men. Biol Psychol, 81(3) ,177-83, http://dx.doi.org/10.1016/j.biopsycho.2009.04.002.

Raynor, D.A., \& Levine, H. (2009). Associations between the five-factor model of personality and health behaviors among college students. Journal of American College Health, 58, 73-81.

Reddy, A., \& Jagannayaki, K. (2018). Stress management among employees in IT Sector. International Journal of Advanced Scientific Technologies, Engineering and Management Sciences, 4(3), 21-23.

Salgado, J. F. (1997). The Five Factor Model of personality and job performance in the European Community. Journal of Applied psychology, 82(1), 30.

Salgado, J. F. (2002). The Big Five personality dimensions and counterproductive behaviors. International Journal of Selection and Assessment, 10(1-2), 117-125.

Sackett, P. R., Berry, C. M., Wiemann, S. A., \& Laczo, R. M. (2006). Citizenship and counterproductive behavior: Clarifying relations between the two domains. Human Performance, 19(4), 441-464.

Savas, A. C., Bozgeyik, Y., \& Eser, I. (2014). A study on the relationship between teacher self-efficacy and burnout. European Journal of Educational Research, 3(4), 159-166. https://doi.org/10.12973/eujer.3.4.159

Schwartz, S.H. (1992). Universals in the content and structure of values: Theory and empirical tests in 20 countries. InM. Zanna (Ed.), Advances in experimental social psychology, 251-65. New York: Academic Press.

Shafiq, M., \& Akram Rana, R. (2016). Relationship of emotional intelligence to organizational commitment of college teachers in Pakistan. Eurasian Journal of Educational Research, 6(2), 1-14.

Sharfras Navar, M. A., \& Vijayakumar, M. (2018). Emotional intelligence: A review of emotional intelligence effect on organizational commitment, job satisfaction and job stress. International Journal of Advanced Scientific Research \& Development, 5(6-1), 1-7.

Shinn, M. Rosario, M., Morch, H. \& Chestnut, D. (1984), "Coping with job stress and burnout in the human services", Journal of personality and social psychology, 46, 864-876.

Skaalvik, E. M., \& Skaalvik, S. (2016). Teacher stress and teacher self-efficacy as predictors of engagement, emotional exhaustion, and motivation to leave the teaching profession. Creative Education, 7, 1785-1799.

Sri, G. P. Z. (2019). Study on stress management among women employees in Trichira palli city. International Journal of Research and Analytical Reviews, 6(1), 240-244.

Stankov, L. (2007). The structure among measures of personality, social attitudes, values, and social norms. Journal of Individual Differences, 28, 240-251.

Suganya, S., \& Rajkumar, A. D. (2016). Job Stress among Teaching Faculty-A Review. International Journal of Applied Engineering Research, 11(2), 1322- 1324. 
Swider, B.W., Zimmerman, R.D. (2010). Born to burnout: A meta-analytic path model of personality, job burnout, and work outcomes. J Vocat Behav, 76(3), 487-506, http://dx.doi.org/10.1016/j.jvb.2010.01.003.

Thoresen, C., Kaplan, S., Barsky, A.P., Warren, C., \& de Chermont, K. The affective underpinnings of job perceptions and attitudes: A meta-analytic review and integration. Psychol Bull.

Tucholska, S. (2003). [Teacher burnout]. Lublin: Katolicki Uniwersytet Lubelski. Polish.

Umesh, U. (2016). A Study on the Occupational Stress among Selected Female Bank Employees Working in the Middle Level Hierarchy Cadre of Indian Bank (Public Sector) and ICICI (Private Sector) in the Southern Malabar region of Kerala State, India. International Journal of Recent Advances in Organizational Behaviour and Decision Sciences, 2(3), 809-817.

Van der Linden, D., Beckers, D.G., \& Taris, T.W. (2007). Reinforcement sensitivity theory at work: Punishment sensitivity as a dispositional source of job-related stress. Eur J Pers. , 21(7), 889-909, http://dx.doi.org/10.1002/per.660.

Van der Walt, H., Meiring, D., Rothmann, S., \& Barrick, M. (2002). Meta-analysis of the relationship between personality measurements and job performance in South Africa. Paper presented at the 5th Annual Industrial Psychology Conference, June, Pretoria

Veugelers, W., \& Vedder, P. (2003). Values in teaching. Teach Theor Pract, 9(4), 377-89, http://dx.doi.org/10.1080/ 1354060032000097262.

Vijayadurai, J., \& Venkatesh, S. (2012). A Study on Stress Management among Women College Teachers in Tamilnadu, India. Pacific Business Review International, 5(2), 50-59.

Witt, L., Burke, L. A., Barrick, M. R., \& Mount, M. K. (2002). The interactive effects of conscientiousness and agreeableness on job performance. Journal of Applied psychology, $\quad 87(1), 164$.

Xin, Y., Wu, J., Yao, Z., Guan, Q., Aleman, A., \& Luo, Y. (2017). The relationship between personality and the response to acute psychological stress, Scientific Reports, 7 (16906), 1-8.

Zhou, S., Da, S., Guo, H., \& Zhang, X. (2018). Work-Family Conflict and Mental Health among Female Employees: A Sequential Mediation Model via Negative Affect and Perceived Stress. Frontiers in psychology, 9, 544. 